\title{
Chemopreventive Potential of Synergyl and Soybean in Reducing Azoxymethane-Induced Aberrant Crypt Foci in Fisher 344 Male Rats
}

\author{
V. P. Gourineni, ${ }^{1}$ M. Verghese, ${ }^{1}$ J. Boateng, ${ }^{1}$ L. Shackelford, ${ }^{1}$ and K. N Bhat ${ }^{2}$ \\ ${ }^{1}$ Nutritional Biochemistry and Carcinogenesis Laboratory, Department of Food and Animal Sciences, Alabama A\&M University, \\ P.O. Box 1628, Normal, AL 35762, USA \\ 2 Department of Chemistry, Alabama A\&M University, Normal, AL 35762, USA
}

Correspondence should be addressed to M. Verghese, martha.verghese@aamu.edu

Received 15 November 2009; Revised 22 June 2010; Accepted 16 January 2011

Academic Editor: Michael M. Müller

Copyright () 2011 V. P. Gourineni et al. This is an open access article distributed under the Creative Commons Attribution License, which permits unrestricted use, distribution, and reproduction in any medium, provided the original work is properly cited.

\begin{abstract}
Synergy1, a prebiotic composed of Inulin and Oligofructose $(1: 1)$. Soybean meal is a natural source of isoflavones. The objective was to investigate the effects of feeding Synergyl and SM on the incidence of azoxymethane- (AOM-) induced aberrant crypt foci (ACF) in Fisher 344 male rats. Rats (54) were randomly assigned to 9 groups $(n=6)$. Control group (C) was fed AIN-93G and treatment groups Syn 1 and SM at 5\% and 10\% singly and in combinations. Rats were injected with two s/c injections of AOM at 7 and 8 weeks of age at $16 \mathrm{mg} / \mathrm{kg}$ body weight and killed at 17 weeks by $\mathrm{CO}_{2}$ asphyxiation. Colonic ACF enumeration and hepatic enzyme activities were measured. Reductions (\%) in total ACF among treatment groups fed combinations were higher (67-77) compared to groups fed singly (52-64). Synergistic mechanisms among phytochemicals may be responsible suggesting protective role in colon carcinogenesis with implications in food product development.
\end{abstract}

\section{Introduction}

Cancer is a major public health problem and statistics show that colon cancer is the third leading cause of cancer deaths among men and women in the USA [1]. Primary prevention is a promising and cost-effective approach in reducing morbidity and mortality related to cancer. Geographical variations in colon cancer prevalence are higher in industrialized nations compared to developing countries which may be explained by the influence of environmental factors such as diet [2]. Diet is one of the modifiable risk factors which has been found to influence colonic microflora and their enzymes in colon carcinogenesis [3-5]. Dietary chemoprevention emerged as one of the strategies targeting multistage pathogenesis [6]. Chemoprevention is defined as "use of natural, synthetic, biological or chemical agents to reverse, suppress, or prevent carcinogenic progression [7-9].

Epidemiological and experimental studies show a correlation with the consumption of dietary fiber and a reduction in colon cancer [10-12]. Synergy1 is a prebiotic composed of Inulin and Oligofructose in equal proportion that has shown inhibitory effects on AOM-induced ACF in F344 rats [13] explained by stimulation of probiotics, production of short chain fatty acids, and activation of detoxifying enzymes [14].

Soybean contains a variety of phytochemicals such as isoflavones, phytates, phytosterols, protease inhibitors, acid phenolics, saponins, and omega-3 fatty acids with numerous health benefits such as lowering plasma cholesterol, osteoporosis, prostate, and breast cancer $[15,16]$. Isoflavones are phytoestrogens available as glycosides in plants and are transformed to aglycones in the human intestine. Action of intestinal $\beta$-glucosidases results in increased absorption and bioavailability of these bioactive compounds and formation of metabolites such as equol, O-desmethylangolensin (ODMA) from daidzein, and P-ethylphenol from genistein [17-21]. The human population consists of equol producers and nonequol producers based on interindividual differences in establishment of intestinal microflora [22]. Due to its potential antioxidative properties $[23,24]$ equol has been 
TABle 1: Composition of diets ${ }^{\mathrm{a}}$ (AIN-93G).

\begin{tabular}{|c|c|c|c|c|c|c|c|c|c|}
\hline Ingredients & $\begin{array}{c}\text { Control } \\
\text { (AIN-93G) }\end{array}$ & $\begin{array}{l}\text { Syn } 1 \\
(5 \%) \\
\end{array}$ & $\begin{array}{c}\text { Syn1 } \\
(10 \%)\end{array}$ & $\begin{array}{c}\mathrm{SM} \\
(5 \%) \\
\end{array}$ & $\begin{array}{c}\mathrm{SM} \\
(10 \%) \\
\end{array}$ & $\begin{array}{l}\text { Syn } 1+\text { SM } \\
(5 \%+5 \%) \\
\end{array}$ & $\begin{array}{c}\text { Syn } 1+\text { SM } \\
(10 \%+10 \%)\end{array}$ & $\begin{array}{c}\text { Syn } 1+\text { SM } \\
(5 \%+10 \%)\end{array}$ & $\begin{array}{c}\text { Syn } 1+\text { SM } \\
(10 \%+5 \%) \\
\end{array}$ \\
\hline Syn1 & 0 & 50 & 100 & 0 & 0 & 50 & 100 & 50 & 100 \\
\hline SM & 0 & 0 & 0 & 50 & 100 & 50 & 100 & 100 & 50 \\
\hline Corn starch & 397.5 & 347.5 & 297.5 & 371.5 & 345.5 & 321.5 & 245.5 & 295.5 & 271.5 \\
\hline Casein & 200 & 200 & 200 & 180 & 160 & 180 & 160 & 160 & 180 \\
\hline Fiber & 50 & 50 & 50 & 46 & 42 & 46 & 42 & 42 & 46 \\
\hline $\begin{array}{l}\text { Common } \\
\text { Ingredients }\end{array}$ & 352.5 & 352.5 & 352.5 & 352.5 & 352.5 & 352.5 & 352.5 & 352.5 & 352.5 \\
\hline
\end{tabular}

${ }^{\mathrm{a}}$ Formulations of diets based on AIN-93G (Reeves et al., 1993 ${ }^{\mathrm{a}, \mathrm{b}}$ ).

${ }^{\mathrm{b}}$ CommonC ingredients (g): soybean oil: $70 \mathrm{~g}$; mineral mix (AIN-93G): 35; vitamin mix: 10; L-cysteine: 3; choline bitartrate: 2.5 .

Abbreviation used: Syn1: Synergy1, SM: Soybean meal, and AIN-93G: American Institute of Nutrition 93 Growth.

reported to reduce the development of chronic diseases such as prostate cancer [25] and cardiovascular diseases [26].

Biomarkers aid in the screening and diagnosis of early stages of pathogenesis [27]. One such early biomarker in colon carcinogenesis is Aberrant Crypt Foci (ACF)—used in prescreening the effects of potential chemopreventive agents and chemical risk assessment in the environment. ACF are microscopic precancerous lesions in the colon capable of progressing to tumors [28]. Azoxymethane (AOM) is a potent carcinogen used to induce colon tumors in rodent models to determine the chemopreventive efficacy of foods [29].

Quantitative assays of specific enzymes activated in response to xenobiotics are useful biomarkers in determining the chemopreventive potential of specific diets $[30,31]$. Glutathione-S-transferases (GSTs) are crucial phase II detoxification enzymes that offer protection by catalyzing conjugation resulting in excretion of xenobiotics [32, 33]. Catalase is an antioxidative enzyme involved in the detoxification of hydrogen peroxide. Superoxide-dismutase is an essential enzyme involved in the conversion of free radical superoxides to peroxides [34]. Prebiotics may influence isoflavone metabolism that can constitute a novel approach in inducing beneficial microflora such as equol-producing and lactic acid bacteria responsible for healthy bowel function. Previous research on health benefits of Synergyl and Soybean has provided a platform to investigate the effects of Synergyl and Soybean meal (SM) singly and in combinations at 5\% and $10 \%$ on the incidence of aberrant crypt foci (ACF) in Fisher 344 male rats and explore the selected mechanisms of action.

\section{Methods and Materials}

2.1. Animal Housing and Diets. Fifty-four Fisher 344 male weanling rats ( 3 weeks old) were obtained from Harlan, IN and housed in stainless steel wire cages at 2 rats per cage. After one week of acclimatization all rats were randomly assigned to nine groups $(n=6)$ and fed the following diets: AIN-93G as control (C) [35] and treatment groups with C+ Synergy1 (5\%, 10\%), C+ SM (5\%, 10\%), C+ Synergy1 + SM $(5 \%+5 \%),(10 \%+10 \%),(5 \%+10 \%)$, and $(10 \%+$ $5 \%)$. Dietary modifications were made to fiber, casein, and cornstarch (Table 1). All rats were housed and maintained according to standard protocols. Biweekly body weights and daily feed intakes were recorded. The diets were prepared fresh and stored at $4^{\circ} \mathrm{C}$. Dietary ingredients were obtained from MP Biomedicals, Costa Mesa, CA. Synergy1 (Beneo) was obtained from Orafti (Teinen, Belgium) and SM was obtained from the local market (Garden Cove, Huntsville, AL). The Institutional Animal Care and Use Committee of Alabama A\&M University approved all protocols involving the experiment.

2.2. Carcinogen Injection. All rats except saline controls received two subcutaneous injections of AOM in saline (National Chemical Repository, Kansas City, MO) for ACF induction at $16 \mathrm{mg} / \mathrm{kg}$ body at 7 and 8 weeks of age. At 17 weeks of age, rats were killed using $\mathrm{CO}_{2}$ asphyxiation following an overnight fast.

2.3. Sample Collection. The cecum from each rat was excised, weighed and split open, and the $\mathrm{pH}$ of the cecal content was measured. Livers of rats were excised and stored at $-80^{\circ} \mathrm{C}$ until analysis.

2.4. Enumeration of Aberrant Crypt Foci (ACF). Aberrant crypt foci scoring (ACF) was done as described by Bird [36]. Briefly, excised colons were flushed with phosphate buffer solution (0.1 M, pH 7.2) (Fisher Scientific, Suwannee, GA) fixed on filter paper with $10 \%$ buffered formalin (Fisher Scientific, Suwannee, GA). Fixed colons were sectioned into proximal (closer to the cecum) and distal portions (closer to the rectal end) of equal length. The colon segments were stained with a $0.2 \%$ methylene blue solution (Sigma chemicals, St. Louis, MO), and ACF were scored microscopically.

2.5. Preparation of Liver Samples for Measuring Hepatic Enzyme Activity. One gram of liver sample was homogenized in $10 \mathrm{~mL}$ of potassium phosphate buffer $(\mathrm{pH} 7.2,0.1 \mathrm{M})$ using a Potter-Elvehjem homogenizer (Model 985370395, Fisher Scientific, Suwannee, GA). The homogenate was centrifuged (Eppendorf AG-5418, Fisher Scientific, Suwannee, GA) at $10,000 \times \mathrm{g}$ for $30 \mathrm{~min}$ and the supernatant was stored at $4^{\circ} \mathrm{C}$. 
TABLE 2: Feed intake, weight gain, cecal weight, and cecal pH in rats fed Synergyl and Soybean meal.

\begin{tabular}{|c|c|c|c|c|c|}
\hline Groups & Feed intake g/day/rat & Weight gain $(\mathrm{g})$ & Cecal weight (g) & Cecal wall (g) & Cecal pH \\
\hline Control & $17.53 \pm 0.19^{\mathrm{a}}$ & $275.67 \pm 9.60^{\mathrm{a}}$ & $2.58 \pm 0.18^{\mathrm{c}}$ & $1.02 \pm 0.10^{c}$ & $7.40 \pm 0.04^{\mathrm{a}}$ \\
\hline Syn1 5\% & $16.77 \pm 0.19^{\mathrm{a}}$ & $278.33 \pm 6.64^{\mathrm{a}}$ & $3.04 \pm 0.55^{b c}$ & $2.0 \pm 0.30^{\mathrm{b}}$ & $6.79 \pm 0.90^{\mathrm{b}}$ \\
\hline Syn1 10\% & $16.15 \pm 0.47^{\mathrm{a}}$ & $253.33 \pm 10.90^{\mathrm{a}}$ & $5.89 \pm 0.13^{\mathrm{a}}$ & $3.02 \pm 0.06^{\mathrm{a}}$ & $6.26 \pm 1.00^{\mathrm{bc}}$ \\
\hline SM 5\% & $16.59 \pm 0.22^{\mathrm{a}}$ & $254.00 \pm 12.22^{\mathrm{a}}$ & $2.91 \pm 0.60^{c}$ & $1.51 \pm 0.49^{c}$ & $7.00 \pm 1.22^{\mathrm{a}}$ \\
\hline SM $10 \%$ & $17.29 \pm 0.59^{\mathrm{a}}$ & $257.33 \pm 13.73^{\mathrm{a}}$ & $2.91 \pm 0.08^{\mathrm{c}}$ & $1.32 \pm 0.07^{\mathrm{c}}$ & $7.06 \pm 0.82^{\mathrm{a}}$ \\
\hline Syn $15 \%+$ SM 5\% & $16.91 \pm 0.11^{\mathrm{a}}$ & $266.00 \pm 10.69^{\mathrm{a}}$ & $3.70 \pm 0.14^{\mathrm{b}}$ & $2.06 \pm 0.04^{\mathrm{b}}$ & $6.22 \pm 0.74^{\mathrm{bc}}$ \\
\hline Syn1 10\% + SM 10\% & $16.73 \pm 0.16^{\mathrm{a}}$ & $257.00 \pm 9.07^{\mathrm{a}}$ & $5.16 \pm 0.78^{\mathrm{a}}$ & $3.87 \pm 0.19^{\mathrm{a}}$ & $5.99 \pm 0.20^{c}$ \\
\hline Syn $15 \%+$ SM $10 \%$ & $17.65 \pm 0.07^{\mathrm{a}}$ & $250.67 \pm 2.02^{\mathrm{a}}$ & $2.75 \pm 0.21^{\mathrm{c}}$ & $2.33 \pm 0.19^{b}$ & $6.62 \pm 1.11^{\mathrm{b}}$ \\
\hline Syn $110 \%+$ SM $5 \%$ & $16.72 \pm 0.81^{\mathrm{a}}$ & $256.33 \pm 15.37^{\mathrm{a}}$ & $5.12 \pm 0.71^{\mathrm{ab}}$ & $3.76 \pm 0.11^{\mathrm{a}}$ & $6.10 \pm 0.59^{c}$ \\
\hline
\end{tabular}

Values are expressed as means \pm SEM, $n=3$.

${ }^{a b c}$ Means in the same column with the same letter are not significantly different by Tukey's studentized range test $(P \leq .05)$.

Abbreviations used: Syn1: Synergyl and SM: Soybean meal.

TABle 3: Effect of Synergyl and Soybean meal on incidence of aberrant crypt foci (ACF) in colon of Fisher 344 male rats.

\begin{tabular}{lccc}
\hline Groups & Proximal Colon & Distal Colon & Total Colon \\
\hline Control (AIN-93G) & $49 \pm 9.21^{\mathrm{a}}$ & $101 \pm 11.6^{\mathrm{a}}$ & $150^{\mathrm{a}}$ \\
Syn1 5\% & $23 \pm 1.5^{\mathrm{b}}$ & $38 \pm 4.1^{\mathrm{b}}$ & $61^{\mathrm{b}}$ \\
Syn1 10\% & $17 \pm 4.9^{\mathrm{bc}}$ & $37 \pm 12.4^{\mathrm{b}}$ & $54^{\mathrm{b}}$ \\
SM 5\% & $24 \pm 3.0^{\mathrm{b}}$ & $48 \pm 4.0^{\mathrm{b}}$ & $72^{\mathrm{b}}$ \\
SM 10\% & $19 \pm 2.8^{\mathrm{bc}}$ & $44.5 \pm 6.8^{\mathrm{b}}$ & $32 \pm 8.4^{\mathrm{bc}}$ \\
Syn1 5\%+ SM 5\% & $12 \pm 5.5^{\mathrm{bc}}$ & $32 \pm 4.4^{\mathrm{bc}}$ & $42^{\mathrm{c}}$ \\
Syn1 10\%+ SM 10\% & $9 \pm 2.5^{\mathrm{c}}$ & $51 \pm 5.2^{\mathrm{b}}$ & $41^{\mathrm{c}}$ \\
Syn1 5\%+ SM 10\% & $4 \pm 1.7^{\mathrm{c}}$ & $27 \pm 5.2^{\mathrm{c}}$ & $49^{\mathrm{bc}}$ \\
Syn1 10\%+ SM 5\% & $7 \pm 2.4^{\mathrm{c}}$ & & $34^{\mathrm{c}}$ \\
\hline
\end{tabular}

Values are expressed as means \pm SEM; $n=3$.

${ }^{\mathrm{abc}}$ Means in the same column with the same letter are not significantly different by Tukey's studentized range test $(P<.05)$.

Abbreviations used: Syn1: Synergy1 and SM: Soybean meal.

2.6. Glutathione-S-Transferase (GST) Activity. The supernatant from liver samples was mixed with 1 , chloro 2, 4-dinitrobenzene ( $1 \mathrm{mM})$, potassium phosphate buffer $(0.1 \mathrm{M})$, and glutathione $(1 \mathrm{mM})$. Sample $(50-100 \mu \mathrm{L})$ was analyzed using a Cary1/3 UV/VIS dual beam spectrophotometer (Varian, Palo Alto, CA) at $340 \mathrm{~nm}$. The total enzyme activity was measured at the end of $5 \mathrm{~min}$ of reaction.

2.7. Reduced Glutathione (GSH) Assay. Hepatic GSH was estimated using Ellman's reagent [37]. An aliquot of the homogenate was deproteinized by the addition of an equal volume of $4 \%$ sulfosalicylic acid and centrifuged at $17,000 \times \mathrm{g}$ for $15 \mathrm{~min}$ at $2^{\circ} \mathrm{C}$. To the diluted supernatant $(0.5 \mathrm{~mL}), 4.5 \mathrm{~mL}$ of Ellman's reagent was added. Absorbance was read at $412 \mathrm{~nm}$.

2.8. Catalase (CAT) Assay. Hepatic catalase activity was estimated at $240 \mathrm{~nm}$ by monitoring the decomposition of $\mathrm{H}_{2} \mathrm{O}_{2}$ [38]. The reaction mixture $(1 \mathrm{~mL})$ contained $0.02 \mathrm{~mL}$ of liver homogenate in phosphate buffer $(50 \mathrm{mM}, \mathrm{pH} 7.0)$ and $0.1 \mathrm{~mL}$ of $30 \mathrm{mM} \mathrm{H}_{2} \mathrm{O}_{2}$ in phosphate buffer.

2.9. Superoxide-Dismutase (SOD) Assay. Hepatic superoxide-dismutase was assayed as described by Fridovich [39].
To the supernatant $(2.0 \mathrm{~mL}), 2.5 \mathrm{~mL}$ of $0.05 \mathrm{M}$ carbonate buffer and $0.3 \mathrm{mM}$ adrenaline were added and absorbance was measured at $480 \mathrm{~nm}$.

2.10. Bone Mineralization. Specific minerals (Calcium (Ca), Phosphorus (P), Magnesium (Mg), Iron (Fe) and Zinc ( $\mathrm{Zn})$ ) in femur bone samples were quantified using inductively coupled plasma spectroscopy (ICP) following standard protocol AACC Method [40].

2.11. Statistical Analysis. Data were analyzed ( $n$ : triplicates) using SAS 9.1 statistical program (SAS, Cary, NC). Results were analyzed by analysis of variance (ANOVA) and expressed as means \pm SEM. Means were separated using Tukey's studentized range test. Significant differences $(P<$ $.05)$ were determined using one-way ANOVA.

\section{Results and Discussion}

3.1. Feed Intake, Weight Gain, Cecal Weight, and Cecal $p H$. There were no significant differences in feed intake (g) and weight gain (g) among groups (Table 2). Weight gain $(278.3 \mathrm{~g})$ was the highest in rats fed SM (5\%). Cecal weight was significantly $(P<.05)$ higher in treatment 
TABLE 4: Effect of Synergy1 and Soybean meal on total number of AOM-induced Crypts in Fisher 344 male Rats.

\begin{tabular}{lccc}
\hline Groups & Proximal colon & Distal colon & Total colon \\
\hline Control & $141 \pm 24.89^{\mathrm{a}}$ & $310 \pm 40.53^{\mathrm{a}}$ & $444^{\mathrm{a}}$ \\
Syn1 5\% & $53 \pm 5.1^{\mathrm{bc}}$ & $136 \pm 10.8^{\mathrm{b}}$ & $189^{\mathrm{bc}}$ \\
Syn1 10\% & $46 \pm 10.6^{\mathrm{bc}}$ & $128 \pm 28.3^{\mathrm{b}}$ & $174^{\mathrm{c}}$ \\
SM 5\% & $72 \pm 6.1^{\mathrm{b}}$ & $152 \pm 12.9^{\mathrm{b}}$ & $224^{\mathrm{b}}$ \\
SM 10\% & $62 \pm 8.8^{\mathrm{b}}$ & $140 \pm 26.2^{\mathrm{b}}$ & $202^{\mathrm{b}}$ \\
Syn1 5\%+SM 5\% & $31.5 \pm 17.1^{\mathrm{d}}$ & $106 \pm 30.2^{\mathrm{c}}$ & $137.5^{\mathrm{d}}$ \\
Syn1 10\%+SM 10\% & $28 \pm 7.5^{\mathrm{d}}$ & $91 \pm 10.3^{\mathrm{c}}$ & $116^{\mathrm{e}}$ \\
Syn1 5\%+SM 10\% & $22 \pm 10.4^{\mathrm{d}}$ & $121 \pm 19.0^{\mathrm{b}}$ & $144^{\mathrm{d}}$ \\
Syn1 10\%+SM 5\% & $27 \pm 7.1^{\mathrm{d}}$ & $72 \pm 15.0^{\mathrm{d}}$ & $99^{\mathrm{e}}$ \\
\hline
\end{tabular}

Values are expressed as means $\pm \mathrm{SEM} ; n=3$.

abcde Means in the same column with the same letter are not significantly different by Tukey's studentized range test $(P<.05)$. Abbreviations used: Syn1: Synergy1, SM: Soybean meal.

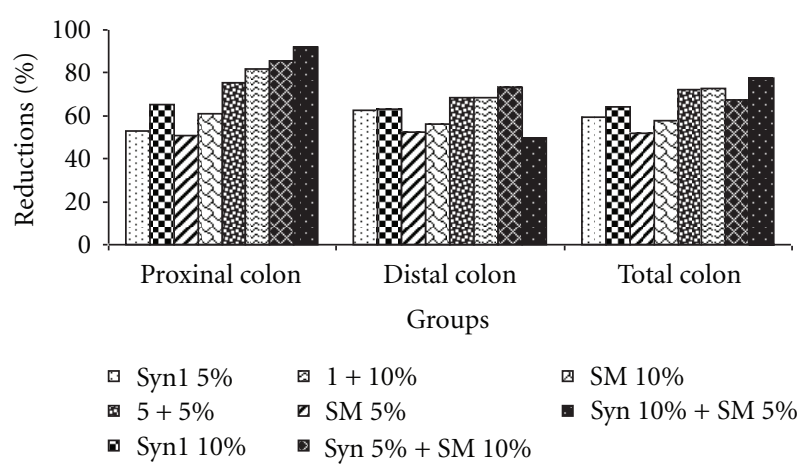

FIGURE 1: Reductions in azoxymethane-induced aberrant crypt foci compared to the control. Abbreviations used: Syn1: Synergyl and SM: Soybean meal.

groups compared to rats fed the control diet. Rats fed Syn1 $(10 \%)$ singly and Syn $1+$ SM (10\%) in combination had significantly $(P<.05)$ higher cecal weight compared to the other treatment groups (Table 2). Cecal $\mathrm{pH}$ ranged from a high of 7.40 in rats fed the control diet to a low of 5.99 in the rats fed Syn $1+$ SM (10\%). Rats fed treatment diets excluding SM $(5 \%)$ and SM $(10 \%)$ had significantly $(P<.05)$ lower cecal $\mathrm{pH}$ compared to the rats fed the control diet (Table 2). The groups fed Syn $1+$ SM $(5+5 \%)$ and Syn $1+$ SM $(10+$ $5 \%)$ had the lowest cecal $\mathrm{pH}$ among groups fed combination diets.

3.2. Incidence of Aberrant Crypt Foci. Incidence of ACF in the distal colon was significantly $(P<.05)$ higher compared to the proximal colon. These results are consistent with previous reported studies [41, 42]. Rats fed treatment diets had significantly $(P<.05)$ lower number of ACF in the distal and proximal colon compared to the rats fed the control diet (Table 3). The rats fed the control diet had the highest number of ACF while the group fed Syn1 (10\%) + SM (5\%) had the lowest number of ACF with a $77.3 \%$ reduction, compared to the control. Total ACF (Table 3 ) ranged from a high of 150 in the control rats to a low of 34 in the rats fed
Syn1 (10) + SM (5\%). Reductions in total ACF compared to the control in rats fed the treatment diets ranged from a high of $77.3 \%$ in the group fed Syn1 (10) + SM (5\%) to a low of $52 \%$ in the group fed SM (5\%) (Figure 1). The groups fed the combination diet with higher concentrations of Syn 1 $(10 \%)+$ SM $(10 \%)$ had the greatest reductions in ACF. Feeding Syn 1 and SM alone at 5\% and $10 \%$ resulted in lower reductions of 59, 64, 52 and $57.6 \%$, respectively, compared to the control. However, when Syn1 was fed in combination with SM at both 5\% and $10 \%$ levels, the reductions were greatly enhanced $(75-91 \%$ in the proximal and $49-73 \%$ in the distal colon compared to the control fed group).

3.3. Total Crypts. Total colonic crypts are precise indicators of the chemopreventive effect of a nutrient or food since it takes into account both the ACF as well as crypts per focus. Total crypts were significantly $(P<.05)$ higher in the rats fed the control compared to those fed treatment diets. Rats fed Syn1 + SM (5\%) and Syn1 + SM (10\%), Syn1 (10\%) + SM $(5 \%)$ and Syn $1(5 \%)+$ SM $(10 \%)$ had significantly $(P<.05)$ lower number of total crypts compared to the other groups fed treatment diets. Total crypts ranged from a high of 440 in the control rats to a low of 99 in the rats fed Syn1 (10\%) + SM (5\%). The reduction in total crypts was enhanced with the addition of SM to Syn1 (Table 4). The reductions in total crypts compared to the control ranged from a low of $49.54 \%$ in the group fed SM (5\%) to a high of $77.70 \%$ in the rats fed Syn1 $(10 \%)+$ SM $(5 \%)$.

3.4. Hepatic GST, GSH, CAT, and SOD. GST activity $(\mu \mathrm{mol} / \mathrm{mg})$ in the treatment groups was significantly $(P<$ .05 ) higher (21.68 to $26.77 \mu \mathrm{mol} / \mathrm{mg}$ ) compared to the control group $(10.58 \mu \mathrm{mol} / \mathrm{mg}$ ) (Table 5). GST activity in the treatment groups was 51 to $60 \%$ higher compared to the control. A similar trend was observed with GSH levels; however GSH levels $(\mathrm{mM})$ were over $90 \%$ higher in the treatment groups compared to the control (Table 5). Catalase (CAT) activity $(\mu \mathrm{mol} / \mathrm{mL})$ in the liver of rats fed the control diet $(0.055)$ (Table 5$)$ was significantly $(P<.05)$ lower compared to the treatment groups. Rats fed treatment diets 
TABle 5: Effect of Synergyl and Soybean meal on glutathione S-transferase, catalase, and superoxide-dismutase activities and reduced glutathione level in Fisher 344 male rats.

\begin{tabular}{|c|c|c|c|c|}
\hline Groups & $\mathrm{GST}(\mu \mathrm{mol} / \mathrm{mg})$ & $\mathrm{GSH}(\mathrm{mM})$ & $\mathrm{CAT}(\mu \mathrm{mol} / \mathrm{mL})$ & $\operatorname{SOD}(\mu \mathrm{mol} / \mathrm{mL})$ \\
\hline Control (AIN-93G) & $10.58 \pm 0.32^{b}$ & $0.17 \pm 0.13^{b}$ & $0.055 \pm 1.50^{\mathrm{b}}$ & $0.107 \pm 0.008^{\mathrm{b}}$ \\
\hline Syn1 5\% & $25.03 \pm 0.81^{\mathrm{a}}$ & $2.15 \pm 0.12^{\mathrm{a}}$ & $0.184 \pm 0.02^{\mathrm{a}}$ & $0.176 \pm 0.013^{\mathrm{a}}$ \\
\hline Syn1 10\% & $21.68 \pm 1.85^{\mathrm{a}}$ & $2.48 \pm 0.13^{\mathrm{a}}$ & $0.170 \pm 0.01^{\mathrm{a}}$ & $0.185 \pm 0.001^{\mathrm{a}}$ \\
\hline SM $5 \%$ & $26.77 \pm 2.56^{\mathrm{a}}$ & $2.18 \pm 0.28^{\mathrm{a}}$ & $0.133 \pm 0.23^{\mathrm{a}}$ & $0.184 \pm 0.008^{\mathrm{a}}$ \\
\hline SM $10 \%$ & $24.31 \pm 0.38^{\mathrm{a}}$ & $2.37 \pm 0.78^{\mathrm{a}}$ & $0.112 \pm 0.01^{\mathrm{a}}$ & $0.190 \pm 0.009^{\mathrm{a}}$ \\
\hline Syn1 5\% +SM 5\% & $25.11 \pm 2.28^{\mathrm{a}}$ & $2.53 \pm 0.27^{\mathrm{a}}$ & $0.149 \pm 0.04^{\mathrm{a}}$ & $0.187 \pm 0.007^{\mathrm{a}}$ \\
\hline Syn1 10\%+SM 10\% & $26.01 \pm 4.04^{\mathrm{a}}$ & $2.98 \pm 0.16^{\mathrm{a}}$ & $0.330 \pm 0.19^{\mathrm{a}}$ & $0.186 \pm 0.005^{\mathrm{a}}$ \\
\hline Syn1 5\% +SM 10\% & $21.81 \pm 0.71^{\mathrm{a}}$ & $2.10 \pm 0.19^{\mathrm{a}}$ & $0.145 \pm 0.02^{\mathrm{a}}$ & $0.190 \pm 0.006^{\mathrm{a}}$ \\
\hline Syn1 10\%+ SM 5\% & $25.28 \pm 1.56^{\mathrm{a}}$ & $2.13 \pm 0.09^{\mathrm{a}}$ & $0.127 \pm 0.03^{\mathrm{a}}$ & $0.186 \pm 0.003^{\mathrm{a}}$ \\
\hline
\end{tabular}

Values are expressed as means $\pm \mathrm{SEM} ; n=3$.

${ }^{\mathrm{abc}}$ Means in the same column with the same letter are not significantly different by Tukey's studentized range test $(P<.05)$.

Abbreviations used: Syn1: Synergy1, SM: Soybean meal, GST: Glutathione S-transferase, GSH: reduced glutathione, CAT: catalase, and SOD: superoxide dismutase.

TABLE 6: Effect of control and treatment diets on Bone mineralization.

\begin{tabular}{|c|c|c|c|c|c|}
\hline Groups & $\mathrm{Ca}(\mathrm{mg} / \mathrm{g})$ & $\mathrm{P}(\mathrm{mg} / \mathrm{g})$ & Mg (mg/g) & $\mathrm{Fe}(\mu \mathrm{g} / \mathrm{g})$ & $\mathrm{Zn}(\mu \mathrm{g} / \mathrm{g})$ \\
\hline Control & $268.5 \pm 11.2^{\mathrm{b}}$ & $122.4 \pm 1.2^{\mathrm{d}}$ & $2.2 \pm 0.1^{\mathrm{c}}$ & $53.1 \pm 0.8^{\mathrm{b}}$ & $163.9 \pm 24.8^{\mathrm{b}}$ \\
\hline Syn1 5\% & $373.1 \pm 2.7^{\mathrm{a}}$ & $145.7 \pm 1.3^{b c}$ & $3.1 \pm 0.05^{\mathrm{ab}}$ & $63.0 \pm 3.3^{\mathrm{ab}}$ & $218.6 \pm 3.6^{\mathrm{ab}}$ \\
\hline Syn1 10\% & $374.6 \pm 5.7^{\mathrm{a}}$ & $147.3 \pm 2.6^{\mathrm{bc}}$ & $3.1 \pm 0.06^{\mathrm{ab}}$ & $65.6 \pm 0.5^{\mathrm{ab}}$ & $231.4 \pm 6.0^{\mathrm{a}}$ \\
\hline SM 5\% & $393.2 \pm 18.9^{\mathrm{a}}$ & $147.4 \pm 3.0^{\mathrm{bc}}$ & $3.1 \pm 0.03^{\mathrm{ab}}$ & $63.9 \pm 2.5^{\mathrm{ab}}$ & $227.4 \pm 19.3^{\mathrm{a}}$ \\
\hline SM $10 \%$ & $353.3 \pm 12.8^{\mathrm{a}}$ & $142.6 \pm 1.5^{\mathrm{c}}$ & $2.8 \pm 0.08^{\mathrm{b}}$ & $58.4 \pm 4.0^{\mathrm{ab}}$ & $214.0 \pm 11.9^{\mathrm{ab}}$ \\
\hline Syn $1+$ SM 5\% & $416.3 \pm 6.8^{\mathrm{a}}$ & $152.4 \pm 1.2^{\mathrm{b}}$ & $3.3 \pm 0.1^{\mathrm{a}}$ & $67.4 \pm 4.6^{\mathrm{a}}$ & $249.6 \pm 5.3^{\mathrm{a}}$ \\
\hline Syn $1+$ SM 10\% & $417.6 \pm 32.4^{\mathrm{a}}$ & $166.2 \pm 1.3^{\mathrm{a}}$ & $3.4 \pm 0.1^{\mathrm{a}}$ & $70.7 \pm 2.9^{a}$ & $250.3 \pm 5.0^{\mathrm{a}}$ \\
\hline Syn1 5\% + SM 10\% & $394.8 \pm 2.8^{\mathrm{a}}$ & $153.9 \pm 1.1^{\mathrm{b}}$ & $3.3 \pm 0.09^{\mathrm{a}}$ & $66.1 \pm 2.4^{\mathrm{ab}}$ & $246.2 \pm 6.6^{\mathrm{a}}$ \\
\hline Syn1 10\% + SM 5\% & $396.3 \pm 6.5^{\mathrm{a}}$ & $152.1 \pm 2.2^{\mathrm{b}}$ & $3.2 \pm 0.07 \mathrm{a}^{\mathrm{b}}$ & $66.6 \pm 1.5^{\mathrm{ab}}$ & $236.2 \pm 1.7^{\mathrm{a}}$ \\
\hline
\end{tabular}

Values are means \pm SEM; $n=3$.

abcd Means in a column with same superscripts do not significantly differ $(P<.05)$.

Abbreviations: Syn1: Synergy1; SM: Soybean meal; Ca: calcium; P: phosphorous, Mg: magnesium; Fe: iron; Zn: zinc.

had 51 to $80 \%$ higher CAT activity $(\mu \mathrm{mol} / \mathrm{mL}$ ) compared to those fed the control diet. Among the rats fed treatments diets, CAT activity was the highest in the rats fed Syn1 + SM (10\%) (0.330) which accounted for an increase of $83 \%$ compared to the control, and the lowest activity was seen in the rats fed SM (10\%) (0.112) accounting for an increase of $51 \%$ compared to the control. There were no differences in CAT activity among treatment groups. SOD activity $(\mu \mathrm{mol} / \mathrm{mL})$ did not differ among rats fed control and treatment diets. However, rats fed the control diet had a lower $(0.107)$ SOD activity $(\mu \mathrm{mol} / \mathrm{mL})$ compared to those fed treatment diets (0.176 to 0.190 ).

3.5. Bone Mineralization. Specific minerals in bone femurs $(\mathrm{Ca}, \mathrm{P}, \mathrm{Mg}, \mathrm{Fe}$, and $\mathrm{Zn})$ were significantly $(P<.05)$ higher in treatment groups compared to control (Table 6). Among treatment groups, rats fed Syn $1+$ SM $(10 \%+10 \%)$ showed the highest retention of these minerals. Calcium $(\mathrm{mg} / \mathrm{g})$ retention in rats fed treatment diets in combinations was over twice compared to the control. Calcium and phosphorus form major composition of bone and involved in its remodeling process.

\section{Discussion}

The ACF model has been used [43-46] to study dietary modulation of colon carcinogenesis. Weight gain and feed intakes among control and treatment groups were similar. Average feed intake ranged from $\approx 16$ to $18 \mathrm{~g} /$ day. Feeding functional foods or dietary ingredients has been reported to affect weight gain in some published studies [47]. However, other researchers [48] did not observe any differences in weight gain or feed intake. Rats fed diets containing Syn 1 $(10 \%)$ singly and in combination with Soybean meal had significantly $(P<.05)$ lower cecal $\mathrm{pH}$ and higher cecal weight which is consistent with previous studies $[49,50]$. The fermentation of soluble fiber by colonic microflora results in the production of SCFA which leads to an increase in cecal weight and decrease in cecal $\mathrm{pH}$. Feeding rats with diets containing $0.3 \%$ grapefruit flavonoid extract, $5 \%$ or $10 \%$ Inulin, and a combination of both supplements resulted 
in a significant enlargement of the cecum compared to rats fed the control diet. Presence of dietary Inulin resulted in a larger cecal mass, over 4-fold higher than the control [51]. Inulin and soybean meal are both significant sources of fiber. Fermentation of fiber leads to the production of short-chain fatty acids such as butyric, propionic, acetic acid, and some gases. Butyrate is the preferred fuel for colonic mucosal cells [52]. Fiber can also increase fecal weight and speed intestinal transit.

Synergy 1 singly and in combination with probiotics exhibited antitumorigenic activity against AOM-induced colon carcinogenesis which was explained by an increased production of cecal short-chain fatty acids (SCFAs) [53]. Prebiotics may modify the activity of beneficial intestinal microflora as a result of the lower cecal $\mathrm{pH}$ resulting in increased solubility of minerals such as calcium in acidic environment that may aid in bone and colonic health as well as increased isoflavone bioavailability [54].

Nutrients play a significant role in induction or inhibition of enzyme activities such as Phase 1 and Phase 2 enzymes that offer protection against xenobiotics by their detoxifying activity $[55,56]$. Glutathione S-transferase (GST) is a phase 2 enzyme involved in conjugation and detoxification of potential carcinogens and its activity is enhanced by products of gut fermentation, such as SCFA [57-59]. Results from our study showed a significantly $(P<.05)$ higher GST activity among treatment groups compared to the control.

A similar study conducted using dietary fructo-oligosaccharides and isoflavone conjugates in ovariectomized mice showed increased $\beta$-glucosidase activity, equol production, and femoral bone mineral density representing contribution of FOS in increasing bioavailability of isoflavones [60]. Defatted Soybean meal flour and whole Soybean meal, good sources of isoflavones reduced the early stages of colon cancer [61].

Results indicate that feeding Synergyl in combination with Soybean meal had protective effects in reducing AOMinduced aberrant crypt foci in Fisher 344 male rats. One of the mechanisms that may explain the chemopreventive potential of Syn1 is the modulation of beneficial gut microflora (equol producing) by fermentation in the distal colon affecting soybean metabolism. Feeding Synergy1 and Soybean meal singly and in combination also enhanced the activity of antioxidative and detoxification enzymes which may have played a significant role in reducing AOM-induced ACF.

\section{Conclusions}

Feeding Synergyl and Soybean in combination showed their potential health benefits in prevention of aberrant crypt foci in F344 male rats. However, ACF studies in rodents may be limited to evaluate the effects of functional foods over longer duration as advancement in cancer pathology is complex where ACF value to predict tumor outcome may decline [62]. Studies evaluating the combinational effects of Synergyl and Soybean on end point tumor biomarkers, colon cancer specific genes, and signaling pathways may provide an insight on their synergism contributing to colon cancer prevention.

\section{Acknowledgments}

This study was supported by Orafti, Tienen, Belgium, and the Alabama Agricultural Experiment Station, Alabama A\&M University, Normal, AL.

\section{References}

[1] American Cancer Society, Facts, Figures and Statistics, ACS, Atlanta, Ga, USA, 2008.

[2] N. S. Painter and D. P. Burkitt, "Diverticular disease of the colon: a deficiency disease of Western civilization," The British Medical Journal, vol. 2, no. 759, pp. 450-454, 1971.

[3] B. R. Goldin and S. L. Gorbach, "The relationship between diet and rat fecal bacterial enzymes implicated in colon cancer," Journal of the National Cancer Institute, vol. 57, no. 2, pp. 371375, 1976.

[4] S. L. Gorbach, "The intestinal microflora and its colon cancer connection," Infection, vol. 10, no. 6, pp. 379-384, 1982.

[5] S. E. McGarr, J. M. Ridlon, and P. B. Hylemon, "Diet, anaerobic bacterial metabolism, and colon cancer: a review of the literature," Journal of Clinical Gastroenterology, vol. 39, no. 2, pp. 98-109, 2005.

[6] B. Boursi and N. Arber, "Current and future clinical strategies in colon cancer prevention and the emerging role of chemoprevention," Current Pharmaceutical Design, vol. 13, no. 22, pp. 2274-2282, 2007.

[7] B. S. Reddy, "Chemoprevention of colon cancer by dietary administration of naturally-occurring and related synthetic agents," Advances in Experimental Medicine and Biology, vol. 400, pp. 931-936, 1997.

[8] A. S. Tsao, E. S. Kim, and W. K. Hong, "Chemoprevention of cancer," Ca-A Cancer Journal for Clinicians, vol. 54, no. 3, pp. 150-180, 2004.

[9] A. Umar, J. L. Viner, E. Richmond, W. F. Anderson, and E. T. Hawk, "Chemoprevention of colorectal carcinogenesis," International Journal of Clinical Oncology, vol. 7, no. 1, pp. 226, 2002.

[10] D. P. Burkitt, "Epidemiology of large bowel disease: the role of fibre," Proceedings of the Nutrition Society, vol. 32, no. 3, pp. 145-149, 1973.

[11] B. Pool-Zobel, J. Van Loo, I. Rowland, and M. B. Roberfroid, "Experimental evidences on the potential of prebiotic fructans to reduce the risk of colon cancer," British Journal of Nutrition, vol. 87, no. 2, pp. S273-S281, 2002.

[12] M. Verghese, D. R. Rao, C. B. Chawan, L. L. Williams, and L. Shackelford, "Dietary inulin suppresses azoxymethaneinduced aberrant crypt foci and colon tumors at the promotion stage in young Fisher 344 rats," Journal of Nutrition, vol. 132, no. 9, pp. 2809-2813, 2002.

[13] M. Verghese, L. T. Walker, L. Shackelford, and C. B. Chawan, "Inhibitory effects of nondigestible carbohydrates of different chain lengths on azoxymethane-induced aberrant crypt foci in Fisher 344 rats," Nutrition Research, vol. 25, no. 9, pp. 859-868, 2005.

[14] B. L. Pool-Zobel, "Inulin-type fructans and reduction in colon cancer risk: review of experimental and human data," British Journal of Nutrition, vol. 93, pp. S73-S90, 2005.

[15] C. Atkinson, C. L. Frankenfeld, and J. W. Lampe, "Gut bacterial metabolism of the soy isoflavone daidzein: exploring the relevance to human health," Experimental Biology and Medicine, vol. 230, no. 3, pp. 155-170, 2005. 
[16] A. O. Omoni and R. E. Aluko, "Soybean foods and their benefits: potential mechanisms of action," Nutrition Reviews, vol. 63, no. 8, pp. 272-283, 2005.

[17] S. M. Heinonen, A. Hoikkala, K. Wähälä, and H. Adlercreutz, "Metabolism of the soy isoflavones daidzein, genistein and glycitein in human subjects. Identification of new metabolites having an intact isoflavonoid skeleton," Journal of Steroid Biochemistry and Molecular Biology, vol. 87, no. 4-5, pp. 285299, 2003.

[18] K. D. R. Setchell, "Phytoestrogens: the biochemistry, physiology, and implications for human health of soy isoflavones," American Journal of Clinical Nutrition, vol. 68, no. 6, pp. 1333S-1346S, 1998.

[19] K. D. R. Setchell and A. Cassidy, "Dietary isoflavones: biological effects and relevance to human health," Journal of Nutrition, vol. 129, no. 3, pp. 758S-767S, 1999.

[20] J. M. W. Wong and D. J. A. Jenkins, "Carbohydrate digestibility and metabolic effects," Journal of Nutrition, vol. 137, no. 11, pp. 2539S-2546S, 2007.

[21] J. P. Yuan, J. H. Wang, and X. Liu, "Metabolism of dietary soy isoflavones to equol by human intestinal microfloraimplications for health," Molecular Nutrition and Food Research, vol. 51, no. 7, pp. 765-781, 2007.

[22] K. D. R. Setchell, N. M. Brown, and E. Lydeking-Olsen, "The clinical importance of the metabolite equol-A clue to the effectiveness of soy and its isoflavones," Journal of Nutrition, vol. 132, no. 12, pp. 3577-3584, 2002.

[23] J. H. Mitchell, P. T. Gardner, D. B. McPhail, P. C. Morrice, A. R. Collins, and G. G. Duthie, "Antioxidant efficacy of phytoestrogens in chemical and biological model systems," Archives of Biochemistry and Biophysics, vol. 360, no. 1, pp. 142-148, 1998.

[24] G. Rimbach, S. De Pascual-Teresa, B. A. Ewins et al., "Antioxidant and free radical scavenging activity of isoflavone metabolites," Xenobiotica, vol. 33, no. 9, pp. 913-925, 2003.

[25] T. E. Hedlund, W. U. Johannes, and G. J. Miller, "Soy isoflavonoid equol modulates the growth of benign and malignant prostatic epithelial cells in vitro," Prostate, vol. 54, no. 1, pp. $68-78,2003$.

[26] R. Liew, J. K. Williams, P. Collins, and K. T. Macleod, "Soyderived isoflavones exert opposing actions on guinea pig ventricular myocytes," Journal of Pharmacology and Experimental Therapeutics, vol. 304, no. 3, pp. 985-993, 2003.

[27] S. Srivastava, M. Verma, and D. E. Henson, "Biomarkers for early detection of colon cancer," Clinical Cancer Research, vol. 7, no. 5, pp. 1118-1126, 2001.

[28] B. Tudek, R. P. Bird, and W. R. Bruce, "Foci of aberrant crypts in the colons of mice and rats exposed to carcinogens associated with foods," Cancer Research, vol. 49, no. 5, pp. 1236-1240, 1989.

[29] D. E. Corpet and F. Pierre, "Point: from animal models to prevention of colon cancer. Systematic review of chemoprevention in min mice and choice of the model system," Cancer Epidemiology Biomarkers and Prevention, vol. 12, no. 5, pp. 391-400, 2003.

[30] J. M. Matés, "Effects of antioxidant enzymes in the molecular control of reactive oxygen species toxicology," Toxicology, vol. 153, no. 1-3, pp. 83-104, 2000.

[31] L. M. Sanders, C. E. Henderson, M. Y. Hong et al., "An increase in reactive oxygen species by dietary fish oil coupled with the attenuation of antioxidant defenses by dietary pectin enhances rat colonocyte apoptosis," Journal of Nutrition, vol. 134, no. 12, pp. 3233-3238, 2004.
[32] S. C. Cotton, L. Sharp, J. Little, and N. Brockton, "Glutathione S-transferase polymorphisms and colorectal cancer: a HuGE review," American Journal of Epidemiology, vol. 151, no. 1, pp. 7-32, 2000.

[33] W. H. Habig, M. J. Pabst, and W. B. Jakoby, "Glutathione $S$ transferases. The first enzymatic step in mercapturic acid formation," The Journal of Biological Chemistry, vol. 249, no. 22, pp. 7130-7139, 1974.

[34] J. M. Matés, C. Pérez-Gómez, and I. Núñez de Castro, "Antioxidant enzymes and human diseases," Clinical Biochemistry, vol. 32, no. 8, pp. 595-603, 1999.

[35] P. G. Reeves, F. H. Nielsen, and G. C. Fahey, "AIN-93 purified diets for laboratory rodents: final report of the American Institute of Nutrition ad hoc writing committee on the reformulation of the AIN-76A rodent diet," Journal of Nutrition, vol. 123, no. 11, pp. 1939-1951, 1993.

[36] R. P. Bird, "Observation and quantification of aberrant crypts in the murine colon treated with a colon carcinogen: preliminary findings," Cancer Letters, vol. 37, no. 2, pp. 147151, 1987.

[37] J. Sedlak and R. H. Lindsay, "Estimation of total, proteinbound, and nonprotein sulfhydryl groups in tissue with Ellman's reagent," Analytical Biochemistry, vol. 25, pp. 192205, 1968.

[38] H. Aebi, "Catalase in vitro," Methods in Enzymology, vol. 105, pp. 121-126, 1984.

[39] I. Fridovich, "Superoxide dismutases. An adaptation to a paramagnetic gas," The Journal of Biological Chemistry, vol. 264, no. 14, pp. 7761-7764, 1989.

[40] AACC, Approved Methods, 8th edition, 1984.

[41] J. Boateng, M. Verghese, C. B. Chawan et al., "Red palm oil suppresses the formation of azoxymethane (AOM) induced aberrant crypt foci (ACF) in Fisher 344 male rats," Food and Chemical Toxicology, vol. 44, no. 10, pp. 1667-1673, 2006.

[42] Y. E. M. Dommels, S. Heemskerk, H. van den Berg, G. M. Alink, P. J. van Bladeren, and B. van Ommen, "Effects of high fat fish oil and high fat corn oil diets on initiation of AOMinduced colonic aberrant crypt foci in male F344 rats," Food and Chemical Toxicology, vol. 41, no. 12, pp. 1739-1747, 2003.

[43] R. P. Bird and C. K. Good, "The significance of aberrant crypt foci in understanding the pathogenesis of colon cancer," Toxicology Letters, vol. 112-113, pp. 395-402, 2000.

[44] P. Dolara, G. Caderni, and C. Luceri, "Surrogate endpoint biomarkers for human colon carcinogenesis," Toxicology Letters, vol. 112-113, pp. 415-420, 2000.

[45] R. G. Stevens, H. Swede, and D. W. Rosenberg, "Epidemiology of colonic aberrant crypt foci: review and analysis of existing studies," Cancer Letters, vol. 252, no. 2, pp. 171-183, 2007.

[46] H. Xiao, X. Hao, B. Simi et al., "Green tea polyphenols inhibit colorectal aberrant crypt foci (ACF) formation and prevent oncogenic changes in dysplastic ACF in azoxymethane-treated F344 rats," Carcinogenesis, vol. 29, no. 1, pp. 113-119, 2008.

[47] B. S. Reddy, A. Rivenson, K. El-Bayoumy, P. Upadhyaya, B. Pittman, and C. V. Rao, "Chemoprevention of colon cancer by organoselenium compounds and impact of high- or lowfat diets," Journal of the National Cancer Institute, vol. 89, no. 7, pp. 506-512, 1997.

[48] S. Toden, A. R. Bird, D. L. Topping, and M. A. Conlon, "Differential effects of dietary whey, casein and soya on colonic DNA damage and large bowel SCFA in rats fed diets low and high in resistant starch," British Journal of Nutrition, vol. 97, no. 3, pp. 535-543, 2007.

[49] H. Jacobsen, M. Poulsen, L. O. Dragsted, G. Ravn-Haren, O. Meyer, and R. H. Lindecrona, "Carbohydrate digestibility 
predicts colon carcinogenesis in azoxymethane-treated rats," Nutrition and Cancer, vol. 55, no. 2, pp. 163-170, 2006.

[50] M. Verghese, D. R. Rao, C. B. Chawan, and L. Shackelford, "Dietary inulin suppresses azoxymethane-induced preneoplastic aberrant crypt foci in mature Fisher 344 rats," Journal of Nutrition, vol. 132, no. 9, pp. 2804-2808, 2002.

[51] Z. Zduńczyk, J. Juśkiewicz, and I. Estrella, "Cecal parameters of rats fed diets containing grapefruit polyphenols and inulin as single supplements or in a combination," Nutrition, vol. 22, no. 9, pp. 898-904, 2006.

[52] J. H. Cummings, E. W. Pomare, W. J. Branch, C. P. E. Naylor, and G. T. Macfarlane, "Short chain fatty acids in human large intestine, portal, hepatic and venous blood," Gut, vol. 28, no. 10, pp. 1221-1227, 1987.

[53] A. P. Femia, C. Luceri, P. Dolara et al., "Antitumorigenic activity of the prebiotic inulin enriched with oligofructose in combination with the probiotics Lactobacillus rhamnosus and Bifidobacterium lactis on azoxymethane-induced colon carcinogenesis in rats," Carcinogenesis, vol. 23, no. 11, pp. 1953-1960, 2002.

[54] V. Coxam, "Current data with inulin-type fructans and calcium, targeting bone health in adults," Journal of Nutrition, vol. 137, no. 11, pp. 2527S-2533S, 2007.

[55] J. Boateng, M. Verghese, L. Shackelford et al., "Selected fruits reduce azoxymethane (AOM)-induced aberrant crypt foci (ACF) in Fisher 344 male rats," Food and Chemical Toxicology, vol. 45, no. 5, pp. 725-732, 2007.

[56] M. J. Wargovich, "Diallylsulfide and allylmethylsulfide are uniquely effective among organosulfur compounds in inhibiting CYP2E1 protein in animal models," Journal of Nutrition, vol. 136, no. 3, pp. 832S-834S, 2006.

[57] M. N. Ebert, A. Klinder, W. H. M. Peters et al., "Expression of glutathione S-transferases (GSTs) in human colon cells and inducibility of GSTM2 by butyrate," Carcinogenesis, vol. 24, no. 10, pp. 1637-1644, 2003.

[58] B. L. Pool-Zobel, V. Selvaraju, J. Sauer et al., "Butyrate may enhance toxicological defence in primary, adenoma and tumor human colon cells by favourably modulating expression of glutathione S-transferases genes, an approach in nutrigenomics," Carcinogenesis, vol. 26, no. 6, pp. 1064-1076, 2005.

[59] J. Sauer, K. K. Richter, and B. L. Pool-Zobel, "Products formed during fermentation of the prebiotic inulin with human gut flora enhance expression of biotransformation genes in human primary colon cells," British Journal of Nutrition, vol. 97, no. 5, pp. 928-937, 2007.

[60] A. Ohta, M. Uehara, K. Sakai et al., "A combination of dietary fructooligosaccharides and isoflavone conjugates increases femoral bone mineral density and equol production in ovariectomized mice," Journal of Nutrition, vol. 132, no. 7, pp. 2048-2054, 2002.

[61] D. G. Thiagarajan, M. R. Bennink, L. D. Bourquin, and F. A. Kavas, "Prevention of precancerous colonic lesions in rats by soy flakes, soy flour, genistein, and calcium," American Journal of Clinical Nutrition, vol. 68, no. 6, pp. 1394S-1399S, 1998.

[62] J. Raju, "Azoxymethane-induced rat aberrant crypt foci: relevance in studying chemoprevention of colon cancer," World Journal of Gastroenterology, vol. 14, no. 43, pp. 66326635, 2008. 


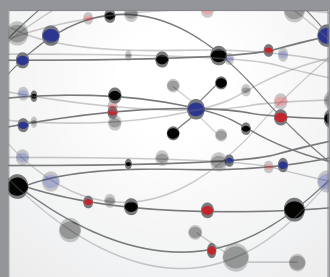

The Scientific World Journal
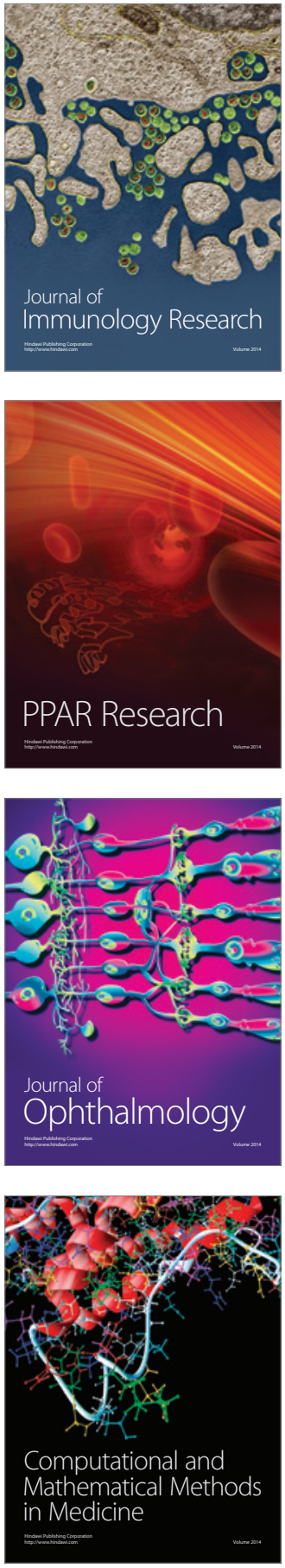

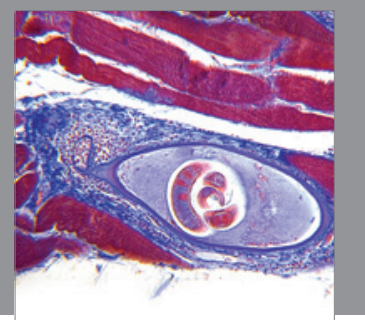

Gastroenterology

Research and Practice
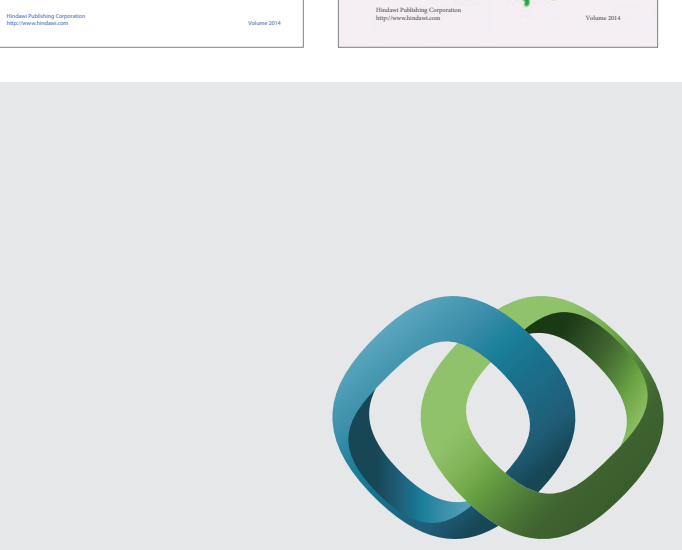

\section{Hindawi}

Submit your manuscripts at

http://www.hindawi.com
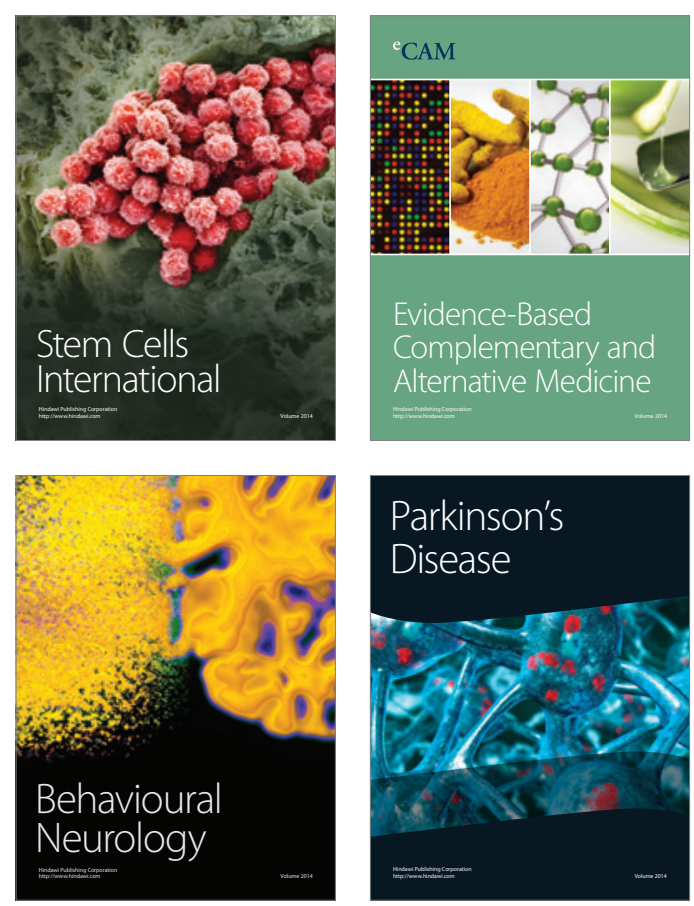

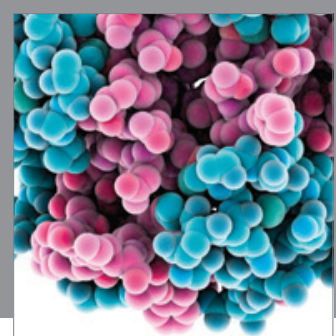

Journal of
Diabetes Research

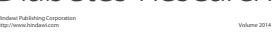

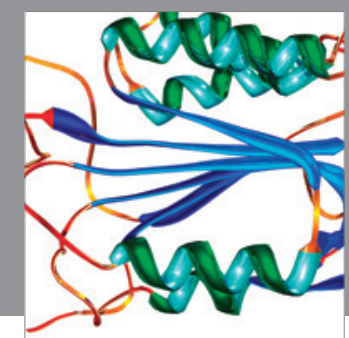

Disease Markers
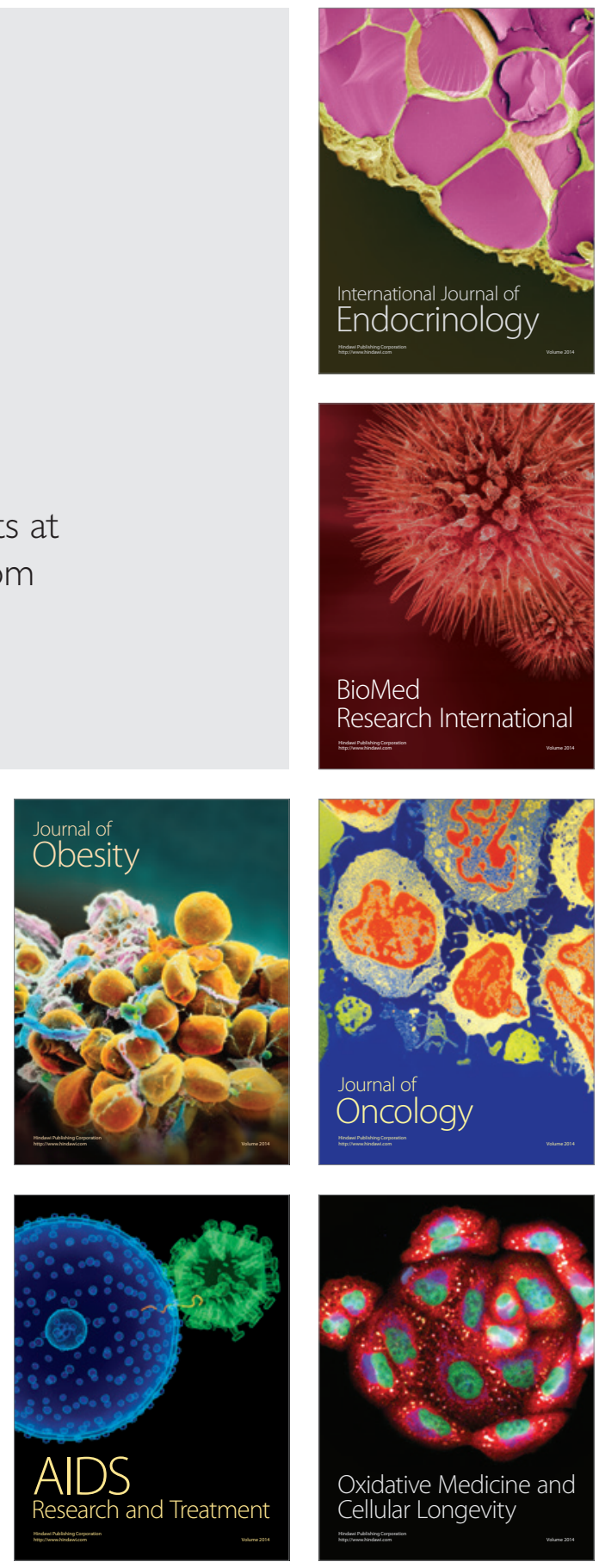